\title{
Immunohistochemical Characterization of Human Synovial Bursa Cells by Light and Transmission Electron Microscopy. Where do These Cells Come From?
}

\author{
Caracterización Inmunohistoquímica de las Células de la Bolsa Sinovial Humana Através de \\ Microscopías de Luz y Transmisión. ¿De dónde Provienen esas Células? \\ "Michael Tobias Hirschmann; ${ }^{* *}$ Albrecht Zschäbitz \& *** Eckart Stofft
}

HIRSCHMANN, M. T.; ZSCHÄBITZ, A. \& STOFFT, E. Immunohistochemical characterization of human synovial bursa cells by light and transmission electron microscopy - Where do these cells come from?. Int. J. Morphol., 25(1):5-14, 2007.

SUMMARY: In the present study human synovial bursa specimens were examined by light and transmission electron microscopy. For light microscopical investigation the bursa tissue was stained with azan, haematoxylin-eosin and monoclonal antibodies (CD14, CD33, CD36, CD68, laminin). For electron microscopical investigation the bursa specimens were fixated with Karnovsky's solution and $1,5 \%$ osmium tetroxide $\left(\mathrm{OsO}_{4}\right)$ in water distilled and contrasted with 5\% uranylacetate and embedded in Epon®.

For the first time the antigenic phenotype was characterized and conclusions were drawn about the origin of the synovial bursa cells. Histologically the bursa was divided in two distinct layers; the intima, which is formed by a lining layer and a lamina propria, and a subintimal layer. The intima consisted of macrophage like (type I) and fibroblast like cells (type II). According to the immunohistochemical staining and the electron microscopy the type I cell seemed to be a bone marrow derived monocyte and the more frequently seen type II cell was derived from subintimal fibroblasts. The intimal bursa cell frequently interdigitated and usually communicated by their filopodia (indirect cell-cell-communication). Neither tight or gap junctions nor desmosomes could be documented.

Although there was no evidence for the existence of a basal lamina, a concentration of extracellular matrix components beyond the bursa cells was observed. In our study there was no accumulation of laminin around the bursal cells, but striking was a vascular bundle of the intima subintima border zone, which was positive for laminin and CD68 and separated the intima from the subintima. In our opinion this histological structure plays an important role in the regeneration of the lining cells and acts like a barrier between bursa and blood.

KEY WORDS: Synovial bursa; CD14 antigen; CD33 antigen; CD68 antigen; Basal lamina.

\section{INTRODUCTION}

Many studies deal with the ultrastructural morphology and origin of synovial lining cells especially focussing on changes in pathological synovial tissue. In contrast only basic knowledge exists about the microscopic structure and the phenotype of synovial cells of communicating or notcommunicating bursa tissue (Moser, 1892; Aschoff, 1919; Hohlbaum, 1923; Key, 1928; Bywaters, 1965 and Becker \& Rauterberg, 1970). To our knowledge, no single study examined either the antigenic phenotype, the type of cell contacts, the existence of a basal lamina or the origin of bursa tissue.
Since the beginning of the $20^{\text {th }}$ century synovial bursa cells are assigned to synovial membrane cells in medical literature (Yasuda et al., 1989; Revell, 1992; Mohr, 1997 and Fox, 1998). The development of histochemical methods have progressed further and no immunohistochemical studies have been performed so far to proof these fundamental, mainly light microscopic findings. The purpose of our study was to investigate the ultrastructural morphology and antigenic phenotype of synovial bursa cells with light and electron microscopy to elucidate their origin in comparison to the synovial joint cells.

\footnotetext{
* MD, Orthopedic Department, Kantonsspital Bruderholz, CH-4101 Bruderholz, Switzerland.

** PD MD, Institute of Anatomy and Cell Biology of the Johannes Gutenberg University, Becherweg 13, 55099 Mainz, Germany.

**** Prof. MD, Institute of Anatomy and Cell Biology of the Johannes Gutenberg University, Becherweg 13, 55099 Mainz, Germany.
} 


\section{MATERIAL AND METHOD}

Tissue samples. Human bursa specimens of 103 patients were obtained during arthroplasties and arthroscopies of hip, knee or shoulder joints. The bursa specimens were received unfixed and either snap frozen in liquid nitrogen or fixed in formaline. Informed consent was obtained from all patients in accordance with the institutional review board. Specimens of 42 hips, five knees, two shoulders of patients with no clinical or histological evidence or history of joint disease or joint effusion were eligible for the study $(n=49$, $\mathrm{m}: \mathrm{w}=20: 29$, mean age $66 \mathrm{yrs}$, range 23-95 yrs). Forty bursa specimens were used for light microscopy and nine were used for electron microscopy.

Light microscopy. A routinely cryo- and paraffine fixation of the bursa specimens was performed. The paraffine or cryostat sections were cut at a thickness of $5 \mu \mathrm{m}$ and 10 $\mu \mathrm{m}$, respectively. Standardized staining with haemotoxylineosin and azan was performed. Five different primary antibodies (CD14 DAKO MO825, CD33 DAKO MO813, CD36 DPC Biermann ANC-185-030, CD68 DAKO M0876, Laminin DAKO 4C7) were used for immunohistochemical staining. The secondary antibody was a canine-anti-mouse-antibody (DAKO E0354).

Transmission electron microscopy. The bursa specimens were initially fixed in Karnovsky's solution ( $\mathrm{pH}$ of 7,4 and $1,5 \%$ osmiumtetroxide $\left(\mathrm{OsO}_{4}\right)$ in water distilled). After graded ethanolic dehydration, the bursa specimens were contrasted with 5\% uranylacetate and embedded in Epon ${ }^{\circledR}$. The Epon ${ }^{\circledR}$ blocks were trimmed, the ultrathin sections cut by an ultramicrotom and finally contrasted with uranylacetate and leadcitrate for 20 minutes. Then the sections were analyzed using an transmission electron microscope EM Leo906.

Statistical analysis. Data were entered into an Excel sheet and analyzed manually. Continuous variables were described using means and ranges. Categorial variables were tabulated with relative frequencies. For the analysis of the antibody staining a representative section of the specimen was divided into a grid screen and the positive stained cells were counted.

\section{RESULTS}

Light microscopy. Structure, form and consistence of the bursa tissue varied with respect to location and mechanical stress. The luminal surface of the bursa was sparsely folded and few microvilli were observed. The bursal wall was divided in intima and subintima. The bursal intima consisted of two separate layers: a flat, compact, non continuous, cellular lining layer and a sparsely cellular, fiber rich lamina propria. The bursal lining layer was made up of one to three layers of heterogeneous, polymorphic cells. Polygonal, elongated or spindle like cells were demonstrated, mostly parallely sometimes however vertically orientated in relation to the luminal surface. Lightmicroscopically four different cell types were noted: a long, thin, spindle like cell; a long, thin, droplet like cell; a short, thick, spindle like cell and a small, round to cuboidal shaped cell. The overall lining layer thickness ranged from 10-20 $\mu \mathrm{m}$. The thickness of the lamina propria was three fold (Figs 1 and 2).

A band-like vascular layer separated the subintima from the intima. The subintima mainly consisted of collagen fibers. Additionally, few spindle-like, flat, soft tissue cells and adipocytes were found. Three major types of subintimal tissue were found: a fiber rich tissue with abundant collagen fibers, an adipose like tissue and a vessel rich soft tissue. The predominant type was the fibrous one. The collagen fibre network of the lamina propria was orientated vertically and in the neighbouring subintima parallely in relation to the surface. The collagen fibers in the intima were thin and singular, in the subintima thicker and bundled.

Laminin antibody staining revealed no evidence for the existance of a real basal membrane beyond the lining layer and thus between intima and subintima. However, areas of increased density of the extracellular matrix beyond the lining layer were observed regularly. Striking was a vascular bundle of the intima subintima border zone, which showed a positive staining with laminin- antibody and CD68 (Figs. 3 and 4).

The paraffine fixed specimens showed reliable and reproducible results only for the CD68 and laminin antibody. Thus for the analysis of CD14, CD33 and CD36 antibody staining only cryostat sections were used. The antibody staining of the bursal cells is shown in Table I. Negative controls for immunohistochemistry showed no staining at all.

Electron transmission microscopy. The cell membrane of the intimal cells generally demonstrated a trilaminar structure. Its surface was characterized by few folds and microvilli. The cellular core was formed irregularly and separated from the cytoplasm by a double-layer membrane. Its mitochondria were ovular shaped and consisted of 


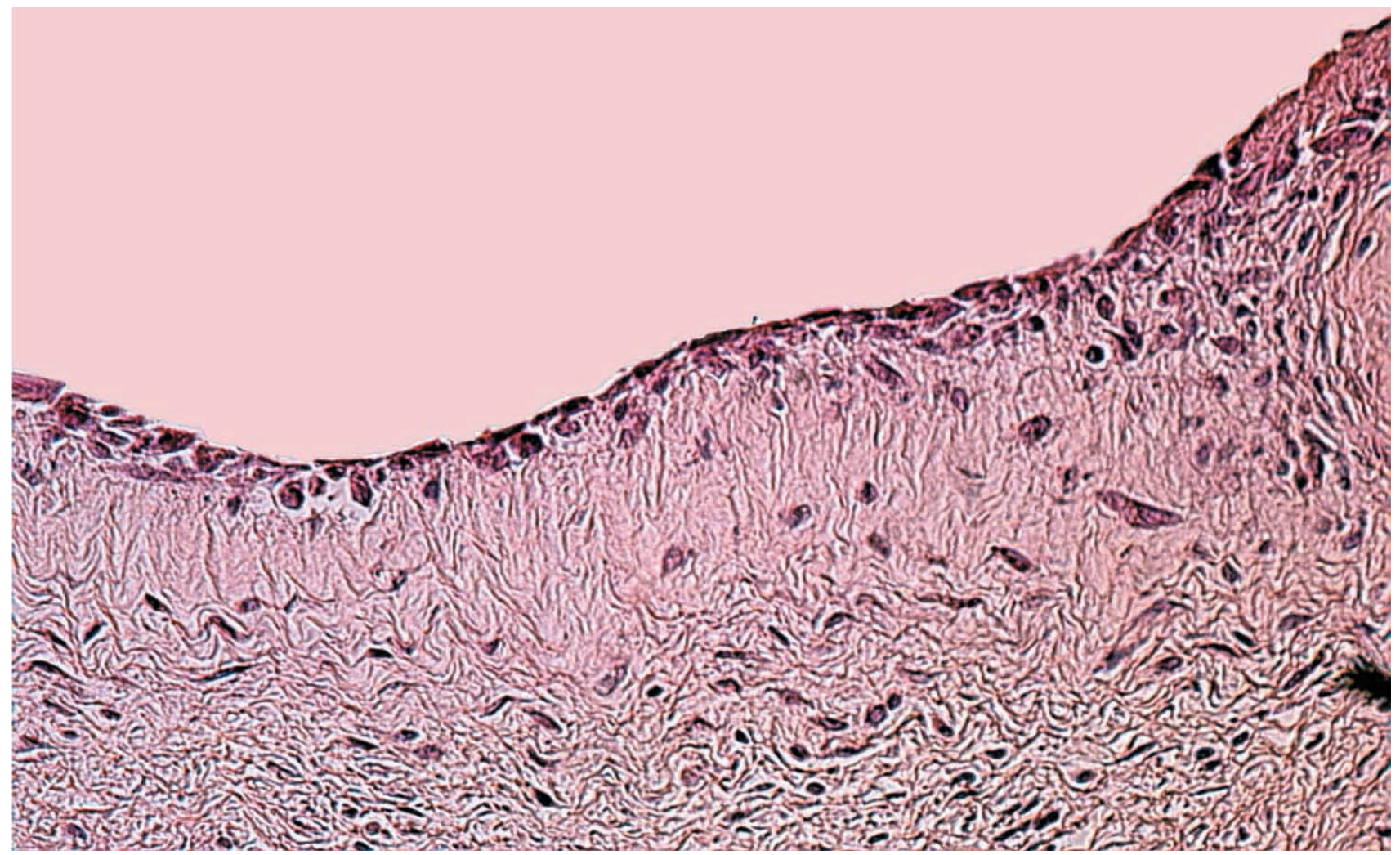

Fig. 1. Intima, divided in a lining layer and a lamina propria, and subintima; paraffine section 5 $\mu \mathrm{m}$, haematoxylin-eosin staining, 20x.

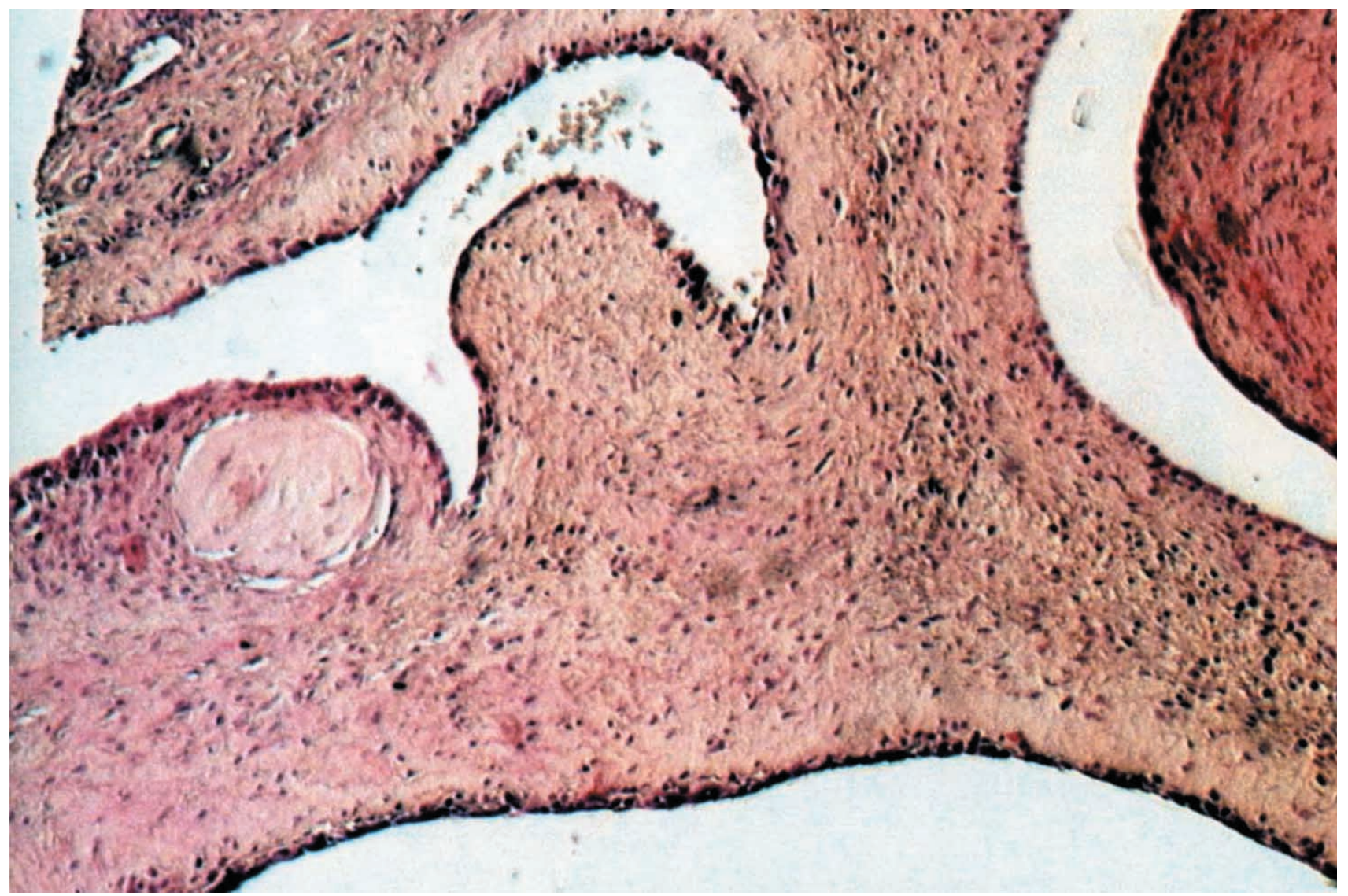

Fig. 2. One to three cell layers thick lining layer and multiple small vessels in the intima subintima border zone; paraffine section $5 \mu \mathrm{m}$, haematoxylin-eosin staining, 10x. 


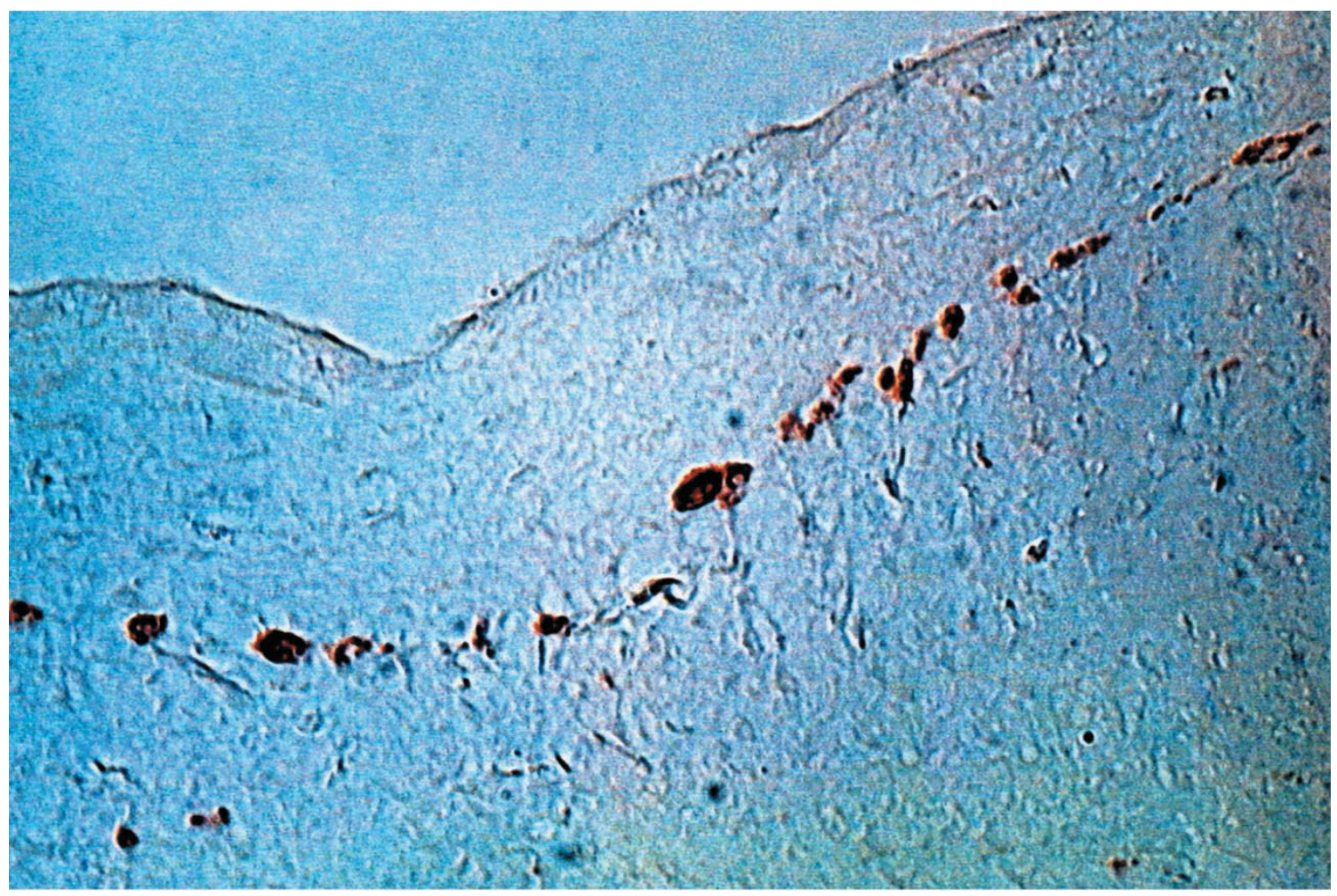

Fig. 3. Band-like CD68 positive cells in the lining layer and in the vascular layer separated the subintima from the intima; paraffine section $5 \mu \mathrm{m}$, CD68 antibody staining, 10x.

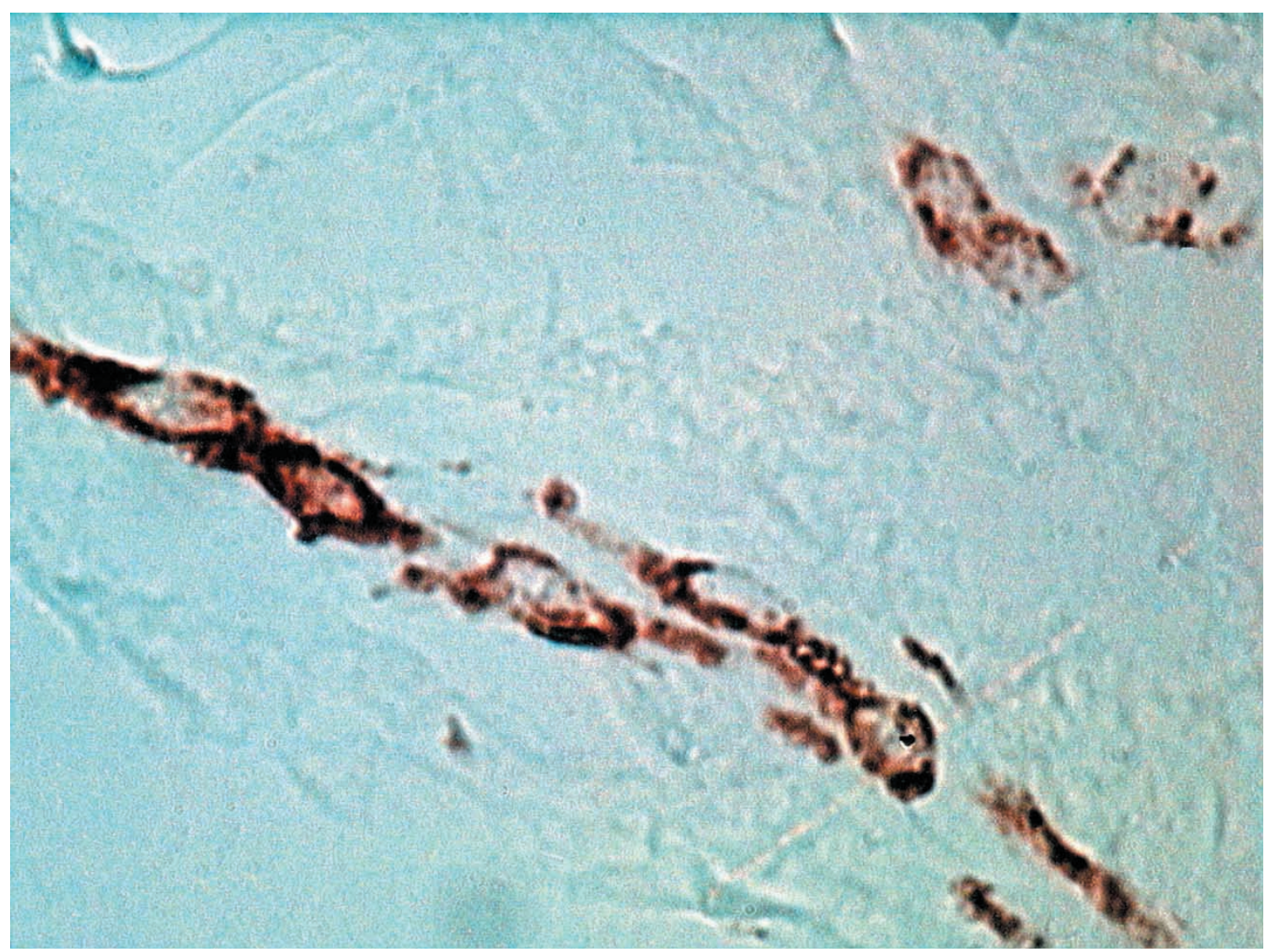

Fig. 4. CD68 positive cells in intima subintima border zone; paraffine section 5 $\mu \mathrm{m}$, CD68 antibody staining, 40x. 
lamellar christae of middle-intense electron density. Besides the rough endoplasmic reticulum free ribosomes were noted.

The cells of the intima can be classified in two groups: A makrophage-like type I intimal cell (type A) and a fibroblast-like type II intimal cell (type B). No intermediate cell types were shown.

The type I intimal cell was characterized by abundant vacuoles and lysosomes, big and dense mitochondria, a nucleus mainly consisting of heterochromatin and a poorly developed rough endoplasmic reticulum. The cell surface was enlarged by several folds and lamellar filopodia. An interdigitation of these cells with neighbouring cells was observed (Figs. 5 and 6).

The fibroblast-like type II intimal cell was flat and spindle-like and characterized by an abundant rough endoplasmatic reticulum, a nucleus mainly consisting of euchromatin and few small filopodia. In the direct neighbourhood many collagen fibers were observed. The type II cell was mainly parallelly orientated to the surface. Long antenna-like processes interdigitating with other intimal cells of the bursal extracellular matrix originated from both of the longitudinal cell poles (Fig. 7).

A real basal lamina separating the intimal cells from the subintima was not demonstrated. However, sparsely condensations of the extracellular matrix beyond the bursal lining cells were shown. The extracellular matrix appeared marmorated and consisted of low to middle dense amorphous material. Around the type II cells many collagen fibers with a periodicity of 64-67 $\mathrm{nm}$ were observed.

There was no evidence for any direct "classic" cellto-cell contacts like tight junctions, gap junctions or desmosomes. However, an indirect cell-to-cell communication by interdigitation of cell filopodia was shown. No free nerve endings were demonstrated in the bursa tissue. The bursa was richly vascularized by smalland middle-calibered blood vessels. Capillaries with mainly non-fenestrated endothelium could be found directly neighbouring the intimal cells and especially in the border zone of intima and subintima.

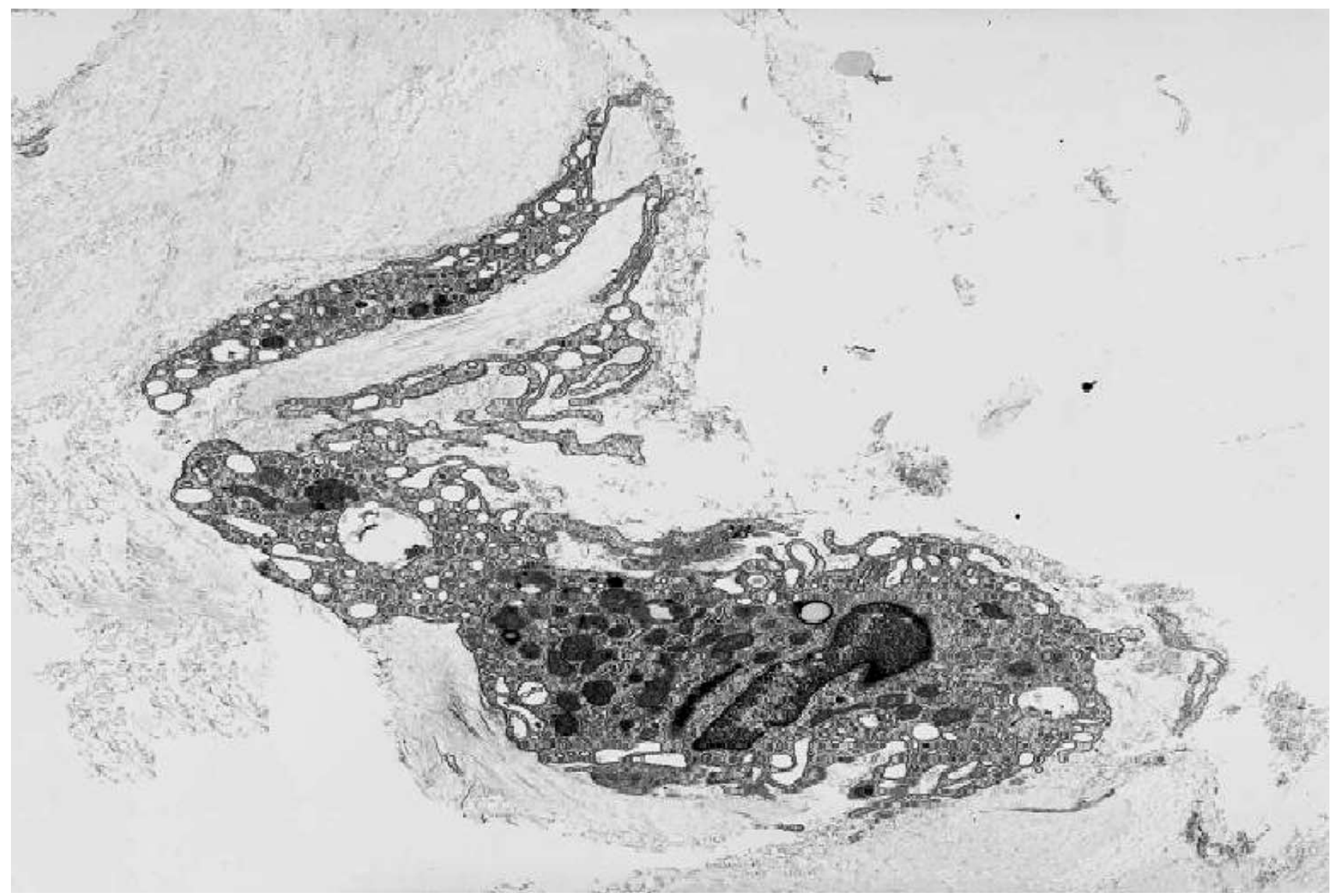

Fig. 5. Macrophage-like type I intimal bursa cell. Transmission electron microscopy, x7750. 


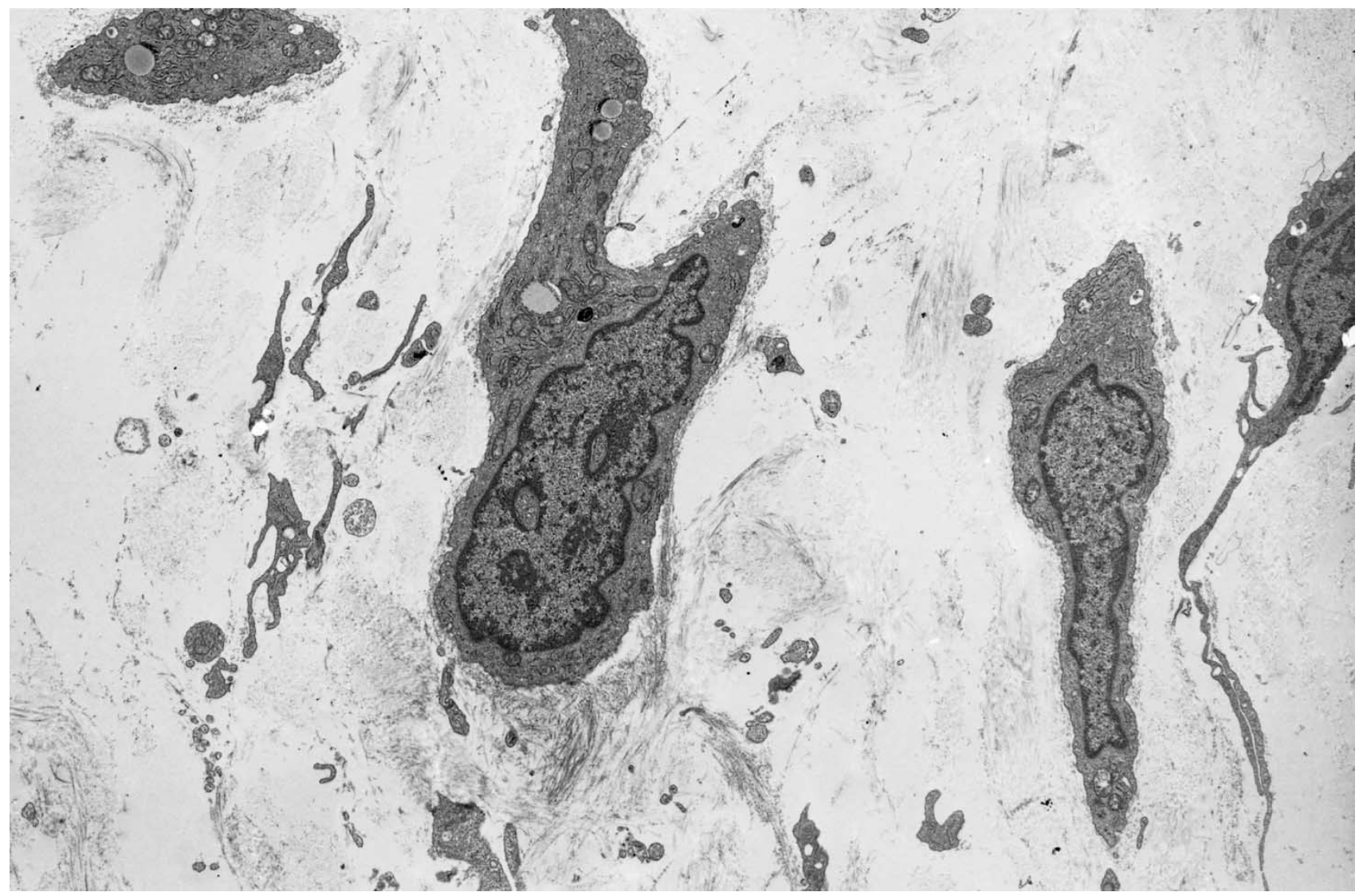

Fig. 6. Macrophage-like type I intimal bursa cell. Transmission electron microscopy, x6000.

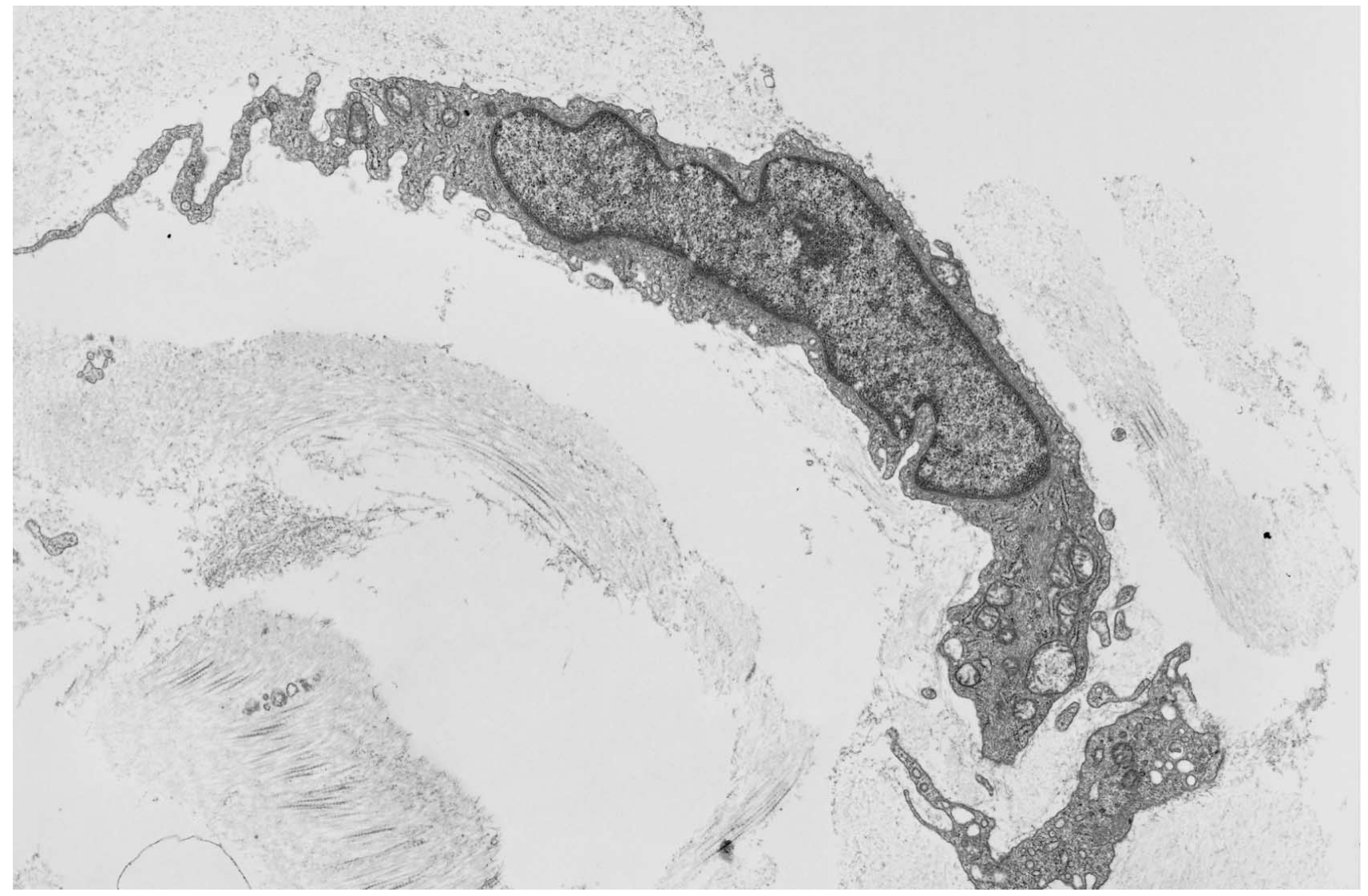

Fig. 7. Fibroblast-like type II intimal bursa cell with filopodia. Transmission electron microscopy, x6000. 
Table I. Expression of different cell markers in intimal, subintimal and endothelial layers

\begin{tabular}{|c|c|c|c|}
\hline Expression of cell markers $+/-$ & Intimal & Subintimal & Endothelial \\
\hline \multicolumn{4}{|c|}{ Cryostate } \\
\hline \multicolumn{4}{|l|}{ CD $14(n=25)$} \\
\hline- & $48 \% / 12$ & $16 \% / 4$ & $100 \% / 25$ \\
\hline+ & $52 \% / 13$ & $84 \% / 21$ & - \\
\hline \multicolumn{4}{|l|}{ CD $33(n=25)$} \\
\hline- & $76 \% / 19$ & $64 \% / 16$ & $100 \% / 25$ \\
\hline+ & $24 \% / 6$ & $36 \% / 9$ & - \\
\hline \multicolumn{4}{|l|}{ CD $36(n=25)$} \\
\hline- & $100 \% / 25$ & $96 \% / 24$ & $100 \% / 25$ \\
\hline+ & - & $4 \% / 1$ & - \\
\hline \multicolumn{4}{|l|}{ CD $68(n=33)$} \\
\hline- & $52 \% / 17$ & $12 \% / 4$ & $100 \% / 33$ \\
\hline+ & $48 \% / 16$ & $88 \% / 29$ & - \\
\hline \multicolumn{4}{|l|}{ Laminin $(n=25)$} \\
\hline- & $80 \% / 20$ & $4 \% / 1$ & - \\
\hline \multirow[t]{2}{*}{+} & $20 \% / 5$ & $96 \% / 24$ & $100 \% / 25$ \\
\hline & \multicolumn{2}{|c|}{ Paraffine } & \\
\hline \multicolumn{4}{|l|}{ CD $68(n=31)$} \\
\hline- & $42 \% / 13$ & $19 \% / 6$ & $100 \% / 31$ \\
\hline+ & $58 \% / 18$ & $81 \% / 25$ & - \\
\hline \multicolumn{4}{|l|}{ Laminin $(n=13)$} \\
\hline- & $46 \% / 6$ & $31 \% / 4$ & $15 \% / 2$ \\
\hline+ & $54 \% / 7$ & $69 \% / 9$ & $85 \% / 11$ \\
\hline
\end{tabular}

\section{DISCUSSION}

With basic light microscopical techniques the bursa and synovial joint tissue seem to have many similarities. Thus it is no wonder that morphologically and functionally bursa tissue has been sumed up under the group of synovial tissue (Yasuda et al.; Revell; Mohr and Fox). Both tissue types show a high structural variability e.g. of their intima. In contrast to synovial tissue, only few folds or microvilli were demonstrated in the bursa tissue specimens in our study.

Fassbender et al., 2002 noted the existence of folds and microvilli to be a special characteristic of synovial joints and neglected it for the bursa tissue.

In contrast to the synovium where the intima is identical to the lining layer (Moser; Lever \& Ford, 1958; Castor \& Fries
1961; Curtiss, 1964; Linck \& Porte, 1978; Soren \& Waugh, 1981; Edwards, 1982, 1995; Graabaek, 1984; McDonald \& Levick, 1988; Revell, 1989; Athanasou \& Quinn, 1991; Carsons \& Wolf, 1995 and Mankin \& Radin, 1998), the bursal intima is divided into a lining layer and a neighbouring lamina propria. The role and existence of a basal lamina of the synovium separating the intima from the subintima is widely discussed and still a matter of controversy. Most authors agree that there is no real basal lamina in the synovium (Lever \& Ford; Barland et al., 1962; Stofft \& Effendy, 1985; Mapp \& Revell, 1988, Pollock et al., 1990). To our knowledge bursa tissue has not been investigated so far. Our findings concerning the existence of a basal lamina in the bursa tissue examined by laminin antibody staining and electron microscopy were in agreement with the results for synovial tissue. 
However, the observed areas of increased density of the extracellular matrix beyond the lining layer were similar to the findings described by Barnett et al. (1961) in the synovium named «external lamina».

McDonald \& Levick and Revell et al. (1995) noted an anchorage of the synovial lining cells similar to a basal lamina in the extracelullar matrix, consisting of fibronectin, laminin, types IV and V collagen and chondroitin sulphate. In our study no accumulation of laminin around the bursal lining cells was observed. However, a vascular bundle of the intima-subintima-border zone being positive for laminin separated the intima from the subintima. In our opinion this histological structure plays an important role in the regeneration of the lining cells and acts as a barrier between bursa and blood. Some authors (Engel, 1940 and Davies \& Palfrey, 1971) discussed the existence of a blood-synoviabarrier in the synovium but were not able to associate a definite ultrastructure to this hypothesis.

Fassbender noted that the cellular lining of the bursa tissue is not a genuine synovial membrane; however the origin of the bursa cells is still unclear.

The CD14- and CD68-positive bursa cells of both intimal and subintimal layers seem to be bone marrowderived macrophage like cells. The distribution of cells showing an increase of these cells from the intimal to the subintimal layer speaks in favor for the regeneration of the bursal macrophage like cell by immigration through the vascular intima subintima border zone. The expression of CD33 on the bursa cells in the intima and more subintimal layers supports the thesis that these bursa cells derive from immigrated myeloid progenitor cells, as this antigen is expressed by early myeloid progenitor cells and macrophages (Auger \& Ross, 1990).

The second type of the bursa tissue is - analogous to the cells of the synovium - formed by fibroblast-like cells. We further characterized this cell type by transmission electron microscopy and demonstrated the increase of this cell type from the intimal to the subintimal layer. For instance the existence of microtubuli-like structures was shown, supporting the thesis of the regeneration of bursal fibroblastlike cells by division of subintimal fibroblasts, as described for the synovium (Dreher, 1982 and Zorn \& Carneiro, 1987).

In the sole transmission electron microscopic study, Becker \& Rauterberg postulated the development of the bursa fibroblast-like cell from mesenchymal tissue.

Our findings of no direct cell-to-cell contacts of the bursa cells and an indirect interdigitation by their cytoplasmic processes and filopodia with a dense extracellular matrix is in contrast to investigations performed on synovial tissue. Most authors affirm the question of cell contacts in the human synovium (Grimley \& Sokoloff, 1966; Ghadially \& Roy, 1969; Ghadially, 1978; Dryll et al., 1980 and Meek et al., 1991). Up to now there have not been any studies on bursa tissue concerning cell contacts.

For further elucidation of the origin of synovial bursa cells additional immunohistochemical light- and electron microscopic studies should be performed.

HIRSChMANN, M. T.; ALBRECHT, Z. \& ECKART, S. Caracterización inmunohistoquímica de las células de la bolsa sinovial humana através de microscopías de luz y transmisión ¿De dónde provienen esas células?. Int. J. Morphol., 25(1):5-14, 2007.

RESUMEN: En el presente estudio se examinaron bolsas sinoviales humanas a través de microscopía de luz y electrónica de transmisión. Para la microscopía de luz, el tejido de las bolsas se tiñó con Azan, H-E y anticuerpos monoclonales (CD14, CD33, CD36, CD68, laminina). Para la microscopía electrónica las bolsas fueron fijadas con solución de Karnovsky y tetróxido de osmio al 1,5\% (OsO4) en agua destilada y contrastada con acetato de uranilo al 5\% y embebido en Epon®.

En primera instacia, el fenotipo antigénico fue caracterizado, concluyéndose acerca del origen de las células que componen la bolsa sinovial. Histológicamente la bolsa fue dividida en dos capas distintas - la íntima - la cual es formada por una capa lineal y una lámina propia, y, una subíntima. La íntima consistió en células parecidas a macrófagos (Tipo I) y células semejantes a fibroblastos (Tipo II). De acuerdo a la tinción inmunohistoquímica y a la microscopía electrónica, las células tipo I parecen provenir de la médula ósea derivada de monocitos y el más frecuente tipo celular II fue derivadado de los fibroblastos de la subíntima. Frecuentemente las células de la íntima de la bolsa se interdigitaban y usualmente se comunicaban a través de sus prolongaciones (comunicación célula indirectacélula). No se observaron ni uniones abiertas, ni cerradas, ni desmosomas.

Aunque no hubo evidencia de la existencia de una lámina basal, se observó una concentración de componentes de matriz extracelular más allá de las células de la bolsa. No hubo acumulación de laminina alrededor de estas células, pero destacada era una banda vascular de la zona límite entre íntima y subíntima, la cual fue positiva para laminina y CD68 la cual separaba la íntima de la subíntima. En nuestra opinión esta estructura histológica juega un importante rol en la regeneración de las células lineales y actúa como una barrera entre la bolsa y la sangre.

PALABRAS CLAVE: Bolsa sinovial; Antígeno CD14; Antígeno D33; Antígeno CD68 ; Lámina basal. 


\section{REFERENCES}

Aschoff, L. Lehrbuch der pathologischen AnatomieSpezieller Teil. 4. ed. 1919. Bywaters, E. G. The Bursae of the Body. Ann. Rheum. Dis., 24:215-8, 1965.

Athanasou, N. A. \& Quinn, J. Immunocytochemical analysis of human synovial lining cells: phenotypic relation to other marrow derived cells. Ann. Rheum. Dis., 50(5):3115, 1991 .

Auger, M. J. \& Ross, J. A. The biology of the macrophage. In: Lewis CEM, J. D., editor. The Macrophage. Oxford, New York, Tokio: Oxford Universiy Press, 1990. pp. 373.

Barland, P. N. et al. Electron microscopy of the human synovial membrane. J. Cell. Biol., 14:207-20, 1962.

Barnett, C. H. et al., ed. Synovial joints. Their structure and mechanics. London, Longmans, 1961.

Becker, W. \& Rauterberg, K. Micromorphology of the lining cells of the bursa. Archiv für orthopädische Unfallchirurgie, 68:197-203, 1970.

Carsons, S. E. \& Wolf, J. Interaction between synoviocytes and extracellular matrix in vitro. Ann. Rheum. Dis., 54(5): 413-6, 1995.

Castor, C.W. \& Fries, F. F. Composition and function of human synovial connective tissue cells measured in vitro. J. Lab. Clin. Med., 57:394-407, 1961.

Curtiss P. H. Changes produced in the synovial membrane and synovial fluid by disease. J. Bone Joint Surg. Am., 46: 873-88, 1964.

Davies, D.V. \& Palfrey, A. J. The fine structure of normal and rheumatoid synovial membrane. In: Hill G, editor. Modern trends in rheumatology. London: Butterworths; 1971. pp. 1-21.

Dreher, R. Origin of synovial type A cells during inflammation. An experimental approach. Immunobiology, 161(3-4):232-45, 1982.

Dryll, A. L. et al. Cellular junctions in normal and inflammatory human synovial membrane revealed by tannic acid and freeze fracture. Virchows Archiv der pathologischen Anatomie, 386:293-302, 1980.
Edwards, J. C. The origin of type A synovial lining cells Immunobiology, 161(3-4): 227-31, 1982.

Edwards, J. C. Synovial intimal fibroblasts. Ann. Rheum. Dis., 54(5): 395-7, 1995.

Engel, D. The permeability of the synovial membrane. $J$. Exp. Phys., 30:231-44, 1940.

Fassbender, H. G. Pathology and Pathobiology of Rheumatic Diseases. $2^{\text {nd }}$ ed. Berlin, Heidelberg, New York, SpringerVerlag, 2002.

Fox, R. I. \& Kang, H. Structure and function of synoviocytes. In: Klippel J. editor. Rheumatology. $2^{\text {nd }}$. ed. London, Mosby, 1998.

Ghadially, F. N. \& Roy, S. Ultrastructure of synovial joints in health and disease. London, Butterworth, 1969.

Ghadially, F. N. Fine structure of synovial joints. In: Sokoloff L. editor. The joints and synovial fluid. New York, Academic Press,1978. p. 140.

Graabaek, P.M. Characteristics of the two types of synoviocytes in rat synovial membrane. Lab. Invest, 50(6): 690-702, 1984.

Grimley, P. M. \& Sokoloff, L. Synovial giant cells in rheumatoid arthritis. Am. J. Pathol., 49:931-54, 1966.

Hohlbaum, J. Die Bursa suprapatellaris und ihre Beziehungen zum Kniegelenk. Bruns Beiträge zur klinischen Chirurgie, 128:481, 1923.

Lever, J. D. \& Ford, E. H. Histological, histochemical and electron microscopic observations on synovial membrane. Anat. Rec., 132(4):525-9, 1958.

Linck, G. \& Porte, A. B-cells of the synovial membrane. II. Differentiation during development of the synovial cavity in the mouse. Cell. Tissue Res., 195(2):251-65, 1978.

Key, J. A. The synovial membrane of joints and bursae. In: Cowdry EV, editor. Special Cytology. New York, Hoeber, P.B., 1928. pp. 1054-74.

Mankin, H. J. \& Radin, E. L. Structure and function of joints. In: Klippel J, editor. Rheumatology. 2 ed. London, Mosby, 1998. 
Mapp, P. I. \& Revell, P. A. Ultrastructural characterisation of macrophages (type A cells) in the synovial lining. Rheumatol. Int., 8:171-6, 1988.

McDonald, J. N. \& Levick, J. R. Morphology of surface synoviocytes in situ at normal and raised joint pressure, studied by scanning electron microscopy. Ann. Rheum. Dis., 47(3):232-40, 1988.

Meek, W. D. et al. Fine structure of the human synovial lining cell in osteoarthritis: its prominent cytoskeleton. Anat. Rec., 231:145-55, 1991.

Moser, E. Beitrag zur Kenntnis der Knieschleimbeutel beim Menschen. Morph. Arb. Jena, 1:267-88, 1892.

Mohr, W. Anatomisch-physiologische Vorbemerkungen. In: Remmele W, editor. Pathologie. Heidelberg, SpringerVerlag, 1997. p. 387.

Pollock, L. E. et al. Type IV collagen and laminin in the synovial intimal layer: an immunohistochemical study. Rheumatol. Int., 9:277-80, 1990.

Revell, P. A. Joint disease. Oxford Textbook of Pathology 27:2075, 1992.

Revell, P. A. et al. Extracellular matrix of the synovial intimal cell layer. Ann. Rheum. Dis., 54:404-7, 1995.

Revell, P. A. Synovial lining cells. Rheumatol. Int., 9(2):49$51,1989$.

Soren, A. \& Waugh, T. R. The giant cells in the synovial membrane. Ann. Rheum. Dis., 40(5):496-500, 1981.

Stofft, E. \& Effendy, W. Development and morphology of rat synovial membrane. Acta Anat (Basel), 121:36-40, 1985.

Yasuda M. et al. Multiple rheumatoid bursal cysts. J. Rheumatol., 16(7):986-8, 1989.

Zorn, T. M. \& Carneiro, J. Cell proliferation in synovial membrane of young mice. Acta Anat (Basel), 128(1):1922, 1987.
Correspondence to:

Dr. Med. Michael Tobias Hirschmann

Orthopedic Department

Kantonsspital Bruderholz

CH-4101 Bruderholz

SWITZERLAND

Telephone: 0041-61-4363158

Fax : 0041-61-4363677

Email:michael.hirschmann@ksbh.ch Michael_Hirschmann@web.de.

Received : 28-08-2006

Accepted : 22-12-2006 